\title{
Determinants of seropositivity among HPV-16/18 DNA positive young women
}

\author{
Carolina Porras ${ }^{1 *}$, Christina Bennett ${ }^{1}$, Mahboobeh Safaeian1', Sarah Coseo', Ana Cecilia Rodríguez², Paula González², \\ Martha Hutchinson ${ }^{3}$, Silvia Jiménez, Mark E Sherman', Sholom Wacholder, Diane Solomon?', \\ Leen-Jan van Doorn ${ }^{4}$, Catherine Bougelet ${ }^{5}$, Wim Quint ${ }^{4}$, Mark Schiffman ${ }^{1}$, Rolando Herrero ${ }^{2}$, Allan Hildesheim ${ }^{1}$, \\ the Costa Rica HPV Vaccine Trial (CVT) Group ${ }^{1}$
}

\begin{abstract}
Background: Not all women infected with HPV-16/18 have detectable levels of HPV-16/18 antibodies, those who seroconvert develop low antibody levels, and seroconversion occurs typically several months post-infection. We evaluated determinants of seropositivity among 646 women infected with HPV-16 and/or HPV-18.

Methods: Data are from the enrollment visit of the NCl-sponsored Costa Rica HPV Vaccine Trial. Sera were tested for HPV-16/18 antibodies by ELISA; cervical specimens were tested for HPV DNA using HC2 and SPF $10 / L i P A_{25}$. Odds ratios (OR) and 95\% confidence intervals (Cl) were computed.

Results: Among HPV-16/18 DNA positives, seropositivity was 63.0\% and 57.5\%, respectively. Among HPV-16 DNA positives, seropositivity increased with lifetime number of sexual partners ( $p$-trend $=0.01)$. Women with abnormal cytology and/or high viral load had a 1.63-2.79-fold increase in the detection of antibodies compared to women with normal cytology/low viral load. Current users of oral contraceptives had a 1.88-fold $(95 \% \mathrm{Cl}, 1.14-3.09)$ increased detection of antibodies and current users of injectables had a 3.38-fold (95\% Cl, 1.39-8.23) increased detection compared to never users. Among HPV-18 DNA positive women, seropositivity was associated with current oral contraceptive use (OR 2.47; 95\%Cl 1.08-5.65).

Conclusions: Factors associated with sustained HPV exposure (abnormal cytology, elevated HPV viral load, increasing lifetime partners) were predictive of HPV-16 seropositivity. Hormonal contraceptive use was associated with seropositivity suggesting an effect of hormones on immune responses to HPV. Patterns were less consistent for HPV-18. Follow up of incident HPV infections to evaluate seroconversion and their determinants is needed.
\end{abstract}

\section{Background}

Infections with most viruses typically result in rapid generation of antibodies that protect against re-infection. In contrast, not all women infected with human papillomavirus (HPV) 16/18 have detectable levels of anti HPV-16/18 antibodies. Women who seroconvert develop low antibody levels and seroconversion occurs within months and varies among women $[1,2]$. The slow and weak antibody response generated by HPV infections could be explained by its life-cycle in the host. HPV is shed within intact cells lining mucosal surfaces,

\footnotetext{
* Correspondence: cporras@proyectoguanacaste.org

'Division of Cancer Epidemiology and Genetics, National Cancer Institute, Bethesda, MD, USA

Full list of author information is available at the end of the article
}

which limits exposure of the host immune system to the virus. HPV infected cells that undergo lysis (i.e. koilocytes) are shed to the environment and infections do not produce viremia. Finally, infections produce a limited load of HPV antigenic proteins [3,4].

Several studies have shown that, as expected, sexual behavior is the strongest predictor of HPV-16/18 antibody detection [5-7]. Other factors identified less consistently (smoking [8,9], oral contraceptive use [7], and history of other sexual transmitted infections [10]) could represent residual confounding by sexual behavior.

In contrast to studies that have evaluated the overall determinants of HPV-16/18 seropositivity, which cannot distinguish risk factors for exposure/infection from those associated with seroconversion given infection, 
little is known about the specific predictors of seropositivity given concomitant infection with cervical HPV-16 or HPV-18. To better understand why some women with cervical HPV-16/18 infection have detectable levels of antibodies while others do not, using data from a community-based HPV-16/18 vaccine trial of 7,466 women aged 18-25 years in Costa Rica, we analyzed the determinants of HPV-16 and18 seropositivity among the subset of 646 women found to be infected with cervical HPV-16 and/or HPV-18 at enrollment.

\section{Methods}

\section{Study population}

Data are from the enrollment (pre-vaccination) visit of a trial investigating efficacy of an HPV-16/18 vaccine to prevent infections and cervical neoplasia in the provinces of Guanacaste and Puntarenas, Costa Rica. The study design and procedures have been described in detail [11]. Briefly, women were identified through a population census and women 18 to 25 years old were invited to participate between June 2004-December 2005. A total of 7,466 , approximately $60 \%$ of eligible women (30.5\% of the census), agreed to participate and fulfilled the inclusion criteria. Eligible women were not hysterectomized, pregnant or lactating, were mentally competent, in good general health, willing to use a contraceptive method during the vaccination phase. Women with a history of chronic or immunodeficiency conditions or with a history of hepatitis A infection or vaccination against it, were excluded.

\section{Study procedures}

At the clinic women gave informed consent and were interviewed. Information regarding sociodemographic factors, reproductive and sexual history, contraceptive use, and smoking were obtained. A physician obtained the medical history and performed a physical exam including a pelvic exam among sexually experienced women. At the pelvic exam, exfoliated cervical cells were collected using a Cervex brush and were rinsed into a vial containing $20 \mathrm{~mL}$ of PreservCyt solution. Samples were transported to the laboratory, where two $0.5 \mathrm{ml}$ aliquots were drawn for HPV DNA testing by PCR. ThinPrep slides were prepared for cytology, and the remaining solution was used for HPV DNA detection by Hybrid Capture 2 (HC2). A blood sample was collected from all participants using a $10 \mathrm{ml}$ vacutainer tube without additive. At the local laboratory serum aliquots for the determination of HPV-16 and HPV-18 antibodies by ELISA were obtained and frozen immediately.

Protocols were approved by the institutional review boards of INCIENSA, Costa Rica and National Cancer Institute, United States.
HPV DNA detection and genotyping by $\mathrm{SPF}_{10} / \mathrm{DEIA} \mathrm{LiPA}_{25}$ system

HPV DNA detection and genotyping was performed at DDL Diagnostic Laboratory (DDL, Voorburg, The Netherlands) using PCR amplification with $\mathrm{SPF}_{10}$ primers followed by DNA enzyme immunoassay detection of amplimers. HPV typing on positive amplimers was performed using line probe assay $\left(\mathrm{LiPA}_{25}\right.$ ) (Labo Biomedical Products, Rijswijk, Netherlands), as previously described [12].

Since the trial uses a bivalent HPV-16/18 vaccine to maximize sensitivity for these types, all specimens that tested positive by $\mathrm{SPF}_{10}$ DEIA but negative for HPV-16 or HPV-18 by $\mathrm{LiPA}_{25}$ were tested for the presence of HPV-16 and HPV-18 using type-specific PCR primers set, as previously described [13,14].

The results of this assay were used to identify the group of women HPV-16 DNA positive or HPV-18 DNA positive at the enrollment visit of the vaccine trial.

\section{HPV DNA detection by Hybrid Capture 2}

$\mathrm{HC} 2$ is a nucleic acid hybridization assay with signal amplification that combines antibody capture of DNA and RNA probe hybrids and chemiluminescent signal detection. The HPV HC2 test is designed to detect 13 carcinogenic HPV types (types 16, 18, 31, 33, 35, 39, 45, $51,52,56,58,59$, and 68 ) without distinguishing the HPV type present. The test was performed according to the manufacturer's instructions in the laboratory at the University of Costa Rica.

With each assay a cut-off RLU (relative light units) value is calculated as the mean RLU value of three positive calibrators. Specimens with relative light units/cutoff $(\mathrm{RLU} / \mathrm{CO})$ value $<1.00$ were considered negative; specimens with $\mathrm{RLU} / \mathrm{CO}$ value $\geq 1.00$ were considered positive for one or more of the carcinogenic HPV types detected by the test. Given that the magnitude of the RLU value above the cutoff of the assay is indicative of the total amount of high risk HPV type present, the results of this assay were used as a surrogate for HPV viral load.

\section{Determination of antibodies against HPV-16/18 L1 VLPs by ELISA}

An enzyme-linked immunosorbent assay (ELISA) was used for the detection and quantitative determination of IgG antibodies against HPV-16 or 18 in serum specimens. HPV-16 and HPV-18 antibodies were measured separately; the assay was performed by GlaxoSmithKline Biologicals as described previously [15]. Briefly, 96 polystyrene well plates (MaxiSorp, Nunc) were coated at $\sim 4^{\circ}$ Celsius with VLP-16 $(2.7 \mu \mathrm{g} / \mathrm{mL})$ or VLP-18 $(2.7 \mu \mathrm{g} / \mathrm{ml})$ which were produced in a baculovirus expression system. After incubation and washing steps, plates were 
blocked with PBS containing 4\% skim milk with $0.2 \%$ Tween 20. Samples were serially diluted in the blocking solution starting at 1/100 in two-fold increments. Serial dilutions of samples, standard, and controls were added to the microtiter plates. After incubation and washing, a peroxidase-conjugated anti-human polyclonal antibody was added to each well. Following incubation and washing the substrate and chromogen were added. The reaction was stopped and the intensity of the yellow color obtained was measured at 450/620 nm. Antibody levels, expressed as ELISA units/mL $(\mathrm{EU} / \mathrm{mL})$, were calculated by interpolation of OD values from the standard curve and by averaging the calculated concentrations obtained in a defined region of the curve. The assay cut-off was defined to be a value above three standard deviations of the geometric mean titer taken from a group of HPVnegative individuals. Seropositivity was defined as a titer greater than or equal to the assay cutoff established as 8 $\mathrm{EU} / \mathrm{mL}$ for HPV-16 and $7 \mathrm{EU} / \mathrm{mL}$ for HPV-18 [16].

\section{Statistical Analysis}

Of the 5871 women that at the enrollment visit had a pelvic exam, 8.3\% (488) were HPV-16 DNA positive, 3.2\% (188) were HPV-18 DNA positive, $0.5 \%$ (30) were HPV-16 and 18 positive. We restricted our analysis to the 484 women HPV-16 DNA positive and the 179 women HPV18 DNA positive with available ELISA results. Additional information regarding the seroprevalence and determinants of HPV16/18 seropositivity for the total population was evaluated in a separate report [17].

Socio-demographic, sexual behavior, contraceptives, smoking and reproductive history characteristics, and cytology and HPV HC2 test results were evaluated as possible determinants of serological response.

For each characteristic, we calculated unadjusted odds ratios (ORs) for seropositivity and 95\% confidence interval (CIs) using unconditional logistic regression. Of particular interest were variables that could be markers of timing of HPV infection (time since sexual debut and time with most recent partner) or of amount/load of exposure (number of sexual partners, viral load by $\mathrm{HC} 2$, cytologic finding, hormonal contraception, and condom use). Possible confounding factors were explored and a final model was built for each characteristic of interest adjusting for all other variables that changed the crude OR estimates by $15 \%$ or more. The outcome variables were seropositivity for antibodies against HPV-16 and seropositivity for antibodies against HPV-18.

We performed a similar set of analyses restricted to women with single HPV-16 and single HPV-18 infections by DNA testing. Results were comparable to those seen overall (data not shown).

From the $\mathrm{HC} 2$ test we used the ratio of relative light unit values to positive control (RLU/CO) as a surrogate for HPV viral load. Women were classified as having low or high viral load based on the median RLU/CO value observed (RLU/CO $\leq 30$ were considered low viral load and RLU/CO > 30 were considered high viral load).

We assessed dose response associations ( $\mathrm{p}$-trend) by treating ordinal variables as continuous assuming a linear trend in the models. $F$ test for differences in geometric means were calculated using ANOVA. Analyses were performed using Stata 10.0.

\section{Results}

Among women who were HPV-16 DNA positive, seropositivity for antibodies against HPV-16 was $63.0 \%$ (305/484); among HPV-18 DNA positive the seropositivity for antibodies against HPV-18 was 57.5\% (103/179).

\section{Determinants of seropositivity among HPV-16 DNA positive women}

As shown in table 1, which presents unadjusted and adjusted risk estimates, there were no differences in the detection of anti-HPV16 antibodies by age (p-trend = 0.73). Among the demographic and sexual behavior factors evaluated, increasing lifetime number of sexual partner was significantly associated with seropositivity. After adjustment for time with most recent partner, women with three or more sexual partners in their lifetime had a 2 -fold increase in the detection of antiHPV16 antibodies compared to women with one lifetime sexual partner $(\mathrm{p}$-trend $=0.01$ ). Increasing frequency of sexual intercourse was indicative of increasing seropositivity; however it was not significant after adjustment for hormonal contraceptives ( $\mathrm{p}$-trend = 0.20).

Age at sexual debut, years since first sexual intercourse and time with most recent partner were not significantly associated with detection of anti-HPV16 antibodies, although suggestive effect was observed for time with most recent partner (OR 1.54; 95\% CI 0.922.58 for $>13$ months versus $<4$ months; $\mathrm{p}$-trend $=$ $0.10)$. Other factors such as years of education and marital status were not associated with seropositivity (data not shown).

Current use of hormonal contraceptives (oral contraceptive pill or injectable) was associated with seropositivity (Table 2). Women who reported use of oral contraceptives during the last month had a 1.88-fold (95\% CI 1.14-3.09) increase in the detection of antiHPV16 antibodies and current users of injectables had a 3.38-fold (95\% CI 1.39-8.23) increase in the detection of anti-HPV16 antibodies compared to never users of hormonal contraceptives. We observed no significant association between condom use and anti-HPV16 antibodies, although there was suggestive evidence for reduced seropositivity among women who reported use 
Table 1 Determinants of seropositivity among HPV-16 DNA positive women at enrollment; Demographic and sexual factors

\begin{tabular}{|c|c|c|c|c|c|c|c|}
\hline \multirow[t]{2}{*}{ Women characteristics } & \multicolumn{3}{|c|}{ Anti-HPV16 } & \multicolumn{2}{|c|}{ Unadjusted } & \multicolumn{2}{|c|}{ Final model $^{1}$} \\
\hline & Negative & Positive & $\%$ & OR & $(95 \% \mathrm{Cl})$ & OR & $(95 \% \mathrm{Cl})$ \\
\hline All women & 179 & 305 & 63.0 & & & & \\
\hline \multicolumn{8}{|l|}{ Age } \\
\hline 18-19 & 50 & 84 & 62.7 & 1.00 & & 1.00 & \\
\hline $20-21$ & 58 & 79 & 57.7 & 0.81 & $(0.50-1.32)$ & 0.74 & $(0.44-1.25)$ \\
\hline $22-23$ & 37 & 71 & 65.7 & 1.14 & $(0.67-1.94)$ & 0.98 & $(0.51-1.86)$ \\
\hline $24-25$ & 34 & 71 & 67.6 & 1.24 & $(0.73-2.13)$ & 1.04 & $(0.53-2.06)$ \\
\hline$p$ trend & & & & & 0.2 & & 0.73 \\
\hline \multicolumn{8}{|l|}{ Age at sexual debut } \\
\hline$\geq 18$ & 53 & 83 & 61.0 & 1.00 & & 1.00 & \\
\hline 17 & 33 & 63 & 65.6 & 1.22 & $(0.71-2.10)$ & 1.22 & $(0.71-2.10)$ \\
\hline 16 & 37 & 60 & 61.9 & 1.04 & $(0.61-1.77)$ & 1.04 & $(0.61-1.77)$ \\
\hline 15 & 34 & 57 & 62.6 & 1.07 & $(0.62-1.85)$ & 1.07 & $(0.62-1.85)$ \\
\hline$<15$ & 22 & 42 & 65.6 & 1.22 & $(0.66-2.27)$ & 1.22 & $(0.66-2.27)$ \\
\hline$p$ trend & & & & & 0.6 & & 0.65 \\
\hline \multicolumn{8}{|c|}{ Years since first sexual intercourse } \\
\hline$\leq 1$ & 23 & 27 & 54.0 & 1.00 & & 1.00 & \\
\hline $2-3$ & 45 & 75 & 62.5 & 1.42 & $(0.73-2.77)$ & 1.28 & $(0.65-2.55)$ \\
\hline $4-5$ & 45 & 74 & 62.2 & 1.40 & $(0.72-2.73)$ & 1.23 & $(0.62-2.46)$ \\
\hline$\geq 6$ & 66 & 129 & 66.2 & 1.66 & $(0.89-3.13)$ & 1.40 & $(0.72-2.73)$ \\
\hline $\mathrm{p}$ trend & & & & & 0.1 & & 0.35 \\
\hline \multicolumn{8}{|c|}{ Frequency sexual intercourse, month } \\
\hline$\leq 1$ & 46 & 48 & 51.1 & 1.00 & & 1.00 & \\
\hline $2-3$ & 26 & 52 & 66.7 & 1.92 & $(1.03-3.57)$ & 1.85 & $(0.98-3.46)$ \\
\hline $4-9$ & 59 & 110 & 65.1 & 1.79 & $(1.07-2.99)$ & 1.55 & $(0.91-2.65)$ \\
\hline$\geq 10$ & 45 & 92 & 67.1 & 1.96 & $(1.14-3.36)$ & 1.57 & $(0.89-2.77)$ \\
\hline $\mathrm{p}$ trend & & & & & 0.0 & & $0.2 C$ \\
\hline \multicolumn{8}{|c|}{ Lifetime number of sexual partners } \\
\hline 1 & 49 & 63 & 56.3 & 1.00 & & 1.00 & \\
\hline 2 & 58 & 92 & 61.3 & 1.23 & $(0.75-2.03)$ & 1.48 & $(0.87-2.50)$ \\
\hline$\geq 3$ & 72 & 150 & 67.6 & 1.62 & $(1.02-2.59)$ & 1.96 & $(1.19-3.25)$ \\
\hline$p$ trend & & & & & 0.0 & & 0.0 \\
\hline \multicolumn{8}{|c|}{ Time with most recent partner, months } \\
\hline$<4$ & 52 & 69 & 57.0 & 1.00 & & 1.00 & \\
\hline $4-13$ & 56 & 98 & 63.6 & 1.32 & $(0.81-2.15)$ & 1.24 & $(0.75-2.05)$ \\
\hline$>13$ & 71 & 138 & 66.0 & 1.46 & $(0.92-2.32)$ & 1.54 & $(0.92-2.58)$ \\
\hline $\mathrm{p}$ trend & & & & & 0.1 & & 0.10 \\
\hline
\end{tabular}

NOTE. HPV, human papillomavirus; OR, odds ratio; Cl, confidence interval.

${ }^{1}$ For each variable considered the final model adjusts for all variables that changed the crude estimate of risk by $15 \%$ or more.

Age: was adjusted for years since first sexual intercourse.

Age at sexual debut: was not adjusted for any co-factors since none of the potential confounders evaluated changed the OR estimates by $15 \%$ or more. Years since first sexual intercourse: was adjusted for use of hormonal contraceptives.

Frequency sexual intercourse, month: was adjusted for use of hormonal contraceptives.

Lifetime number of sexual partners: was adjusted for time with most recent partner.

Time with most recent partner: was adjusted for lifetime number of sexual partners and use of hormonal contraceptives.

of condom at the time of their last sexual intercourse (OR 0.66; 95\% CI 0.42-1.03). To ensure that the higher seropositivity among hormonal contraception users was not confounded by condom use, we evaluated seropositivity and hormonal contraception for all strata of condom use (never, past, and current). We observed that, current users of hormonal contraceptives were more likely to be seropositive compared with never users of hormonal contraceptives in all strata of condom use. Current users of hormonal contraceptives who reported never using condoms had an OR of 2.20 (95\% CI 0.835.81 ) and current users of hormonal contraceptives who 
Table 2 Determinants of seropositivity among HPV-16 DNA positive women at enrollment; Contraceptive, pregnancy, smoking status factors

\begin{tabular}{|c|c|c|c|c|c|c|c|}
\hline \multirow[t]{2}{*}{ Women characteristics } & \multicolumn{3}{|c|}{ Anti-HPV16 } & \multicolumn{2}{|c|}{ Unadjusted } & \multicolumn{2}{|c|}{ Final model $^{1}$} \\
\hline & Negative & Positive & $\%$ & OR & $(95 \% \mathrm{Cl})$ & OR & $(95 \% \mathrm{Cl})$ \\
\hline All women & 179 & 305 & 63.0 & & & & \\
\hline \multicolumn{8}{|l|}{ Use of hormonal contraceptives } \\
\hline Never & 42 & 45 & 51.7 & 1.00 & & 1.00 & \\
\hline In the past & 49 & 70 & 58.8 & 1.33 & $(0.76-2.33)$ & 1.33 & $(0.76-2.33)$ \\
\hline Current oral contraceptives & 80 & 161 & 66.8 & 1.88 & $(1.14-3.09)$ & 1.88 & $(1.14-3.09)$ \\
\hline Current injectable & 8 & 29 & 78.4 & 3.38 & $(1.39-8.23)$ & 3.38 & $(1.39-8.23)$ \\
\hline \multicolumn{8}{|l|}{ Use of condom } \\
\hline Never & 58 & 108 & 65.1 & 1.00 & & 1.00 & \\
\hline In the past & 74 & 143 & 65.9 & 1.04 & $(0.68-1.59)$ & 1.12 & $(0.72-1.73)$ \\
\hline Current (last month) & 47 & 54 & 53.5 & 0.62 & $(0.37-1.02)$ & 0.79 & $(0.46-1.37)$ \\
\hline \multicolumn{8}{|l|}{ Frequency of condom use } \\
\hline Never or rarely & 67 & 128 & 65.6 & 1.00 & & 1.00 & \\
\hline Sometimes & 30 & 47 & 61.0 & 0.82 & $(0.48-1.41)$ & 0.91 & $(0.52-1.59)$ \\
\hline Most of the time & 32 & 52 & 61.9 & 0.85 & $(0.50-1.45)$ & 1.04 & $(0.60-1.81)$ \\
\hline Always & 46 & 78 & 62.9 & 0.89 & $(0.56-1.42)$ & 1.01 & $(0.62-1.65)$ \\
\hline \multicolumn{8}{|c|}{ Use of condom last sexual intercourse } \\
\hline No & 109 & 226 & 67.5 & 1.00 & & 1.00 & \\
\hline Yes & 70 & 79 & 53.0 & 0.54 & $(0.37-0.81)$ & 0.66 & $(0.42-1.03)$ \\
\hline \multicolumn{8}{|l|}{ Number of pregnancies } \\
\hline 0 & 81 & 109 & 57.4 & 1.00 & & 1.00 & \\
\hline 1 & 63 & 125 & 66.5 & 1.47 & $(0.97-2.24)$ & 1.47 & $(0.97-2.24)$ \\
\hline 2 & 24 & 43 & 64.2 & 1.33 & $(0.75-2.37)$ & 1.33 & $(0.75-2.37)$ \\
\hline$\geq 3$ & 11 & 28 & 71.8 & 1.89 & $(0.89-4.02)$ & 1.89 & $(0.89-4.02)$ \\
\hline $\mathrm{p}$ trend & & & & & 0.06 & & 0.06 \\
\hline \multicolumn{8}{|l|}{ Smoking Status } \\
\hline Never smoked for $\geq 6$ months & 140 & 231 & 62.3 & 1.00 & & 1.00 & \\
\hline Former smoker & 15 & 24 & 61.5 & 0.97 & $(0.49-1.91)$ & 0.97 & $(0.49-1.91)$ \\
\hline Current & 24 & 50 & 67.6 & 1.26 & $(0.74-2.15)$ & 1.26 & $(0.74-2.15)$ \\
\hline \multicolumn{8}{|c|}{ Cytology-Hybrid capture, viral load ${ }^{2}$} \\
\hline Normal/Low viral load & 89 & 102 & 53.4 & 1.00 & & 1.00 & \\
\hline LSIL/Low viral load & 7 & 17 & 70.8 & 2.12 & $(0.84-5.34)$ & 2.12 & $(0.84-5.34)$ \\
\hline HSIL/Low viral load & 5 & 16 & 76.2 & 2.79 & $(0.98-7.93)$ & 2.79 & $(0.98-7.93)$ \\
\hline Normal/High viral load & 24 & 61 & 71.8 & 2.22 & $(1.28-3.85)$ & 2.22 & $(1.28-3.85)$ \\
\hline LSIL/High viral load & 31 & 58 & 65.2 & 1.63 & $(0.97-2.75)$ & 1.63 & $(0.97-2.75)$ \\
\hline HSIL/High viral load & 15 & 43 & 75.1 & 2.50 & $(1.30-4.81)$ & 2.50 & $(1.30-4.81)$ \\
\hline
\end{tabular}

NOTE. HPV, human papillomavirus; OR, odds ratio; Cl, confidence interval; LSIL, low grade squamous intraepithelial lesion; HSIL, high grade squamous intraepithelial lesion.

${ }^{1}$ For each variable considered the final model adjusts for all variables that changed the crude estimate of risk by $15 \%$ or more.

Use of hormonal contraceptives: was not adjusted for any co-factors since none of the potential confounders evaluated changed the OR estimates by $15 \%$ or more.

Use of condom: was adjusted for use of hormonal contraceptives.

Frequency of condom use: was adjusted for use of hormonal contraceptives.

Use of condom last sexual intercourse: was adjusted for use of hormonal contraceptives.

Number of pregnancies, smoking status and cytology-hybrid capture, viral load: were not adjusted for any co-factors since none of the potential confounders evaluated changed the OR estimates by $15 \%$ or more.

${ }^{2}$ Low viral load defined as hybrid capture rlu/co $\leq 30$; High viral load defined as hybrid capture rlu/co $>30$. 
reported current use of condom had an OR of 1.90 (95\% CI 0.65-5.51) relative to condom users who did not use hormonal contraception.

Number of pregnancies and smoking were not significantly associated with anti-HPV16 seropositivity (Table 2 ), although there was a tendency for seropositivity to increase with increasing number of pregnancies (OR 1.89; $95 \%$ CI $0.89-4.02$ for $\geq 3$ pregnancies compared to none; $\mathrm{p}$-trend $=0.06$ ).

Cytology and HC2 viral load measures were significantly associated with anti-HPV16 seropositivity (Table 2). Compared to women with a normal cytology and low viral load, those with evidence of SIL (squamous intraepithelial lesion) and/or high viral load had a 1.63 to 2.79 fold increase in the detection of anti-HPV16 antibodies.

Since previous studies have suggested that HPV is responsive to hormonal factors and that hormone levels modulate HPV viral expression $[18,19]$, we examined whether the association between hormonal contraceptive use and anti-HPV16 seropositivity might be explained by elevated viral load among hormonal contraceptive users. Table 3 shows the analysis that compared the geometric mean (GM) for HC2 viral load levels by hormonal contraceptive status. We found no evidence that current hormonal contraceptives users had higher viral loads than never users $(\mathrm{p}=0.66)$.

Among women with antibodies against HPV16 we calculated the GM for anti-HPV16 levels for each category of all the variables evaluated and we did not find significant differences in serological levels, except for cytologyHC2 viral load $(p=0.003)$. Antibody levels were lowest among women with normal cytology and low viral load $(\mathrm{GM}=50.0)$; intermediate among women with either abnormal cytology or high viral load $(\mathrm{GM}=71.5)$; and highest among women with both an abnormal cytology and high viral load (women LSIL/high viral load, GM = 121.1; women HSIL/high viral load, GM = 97.7).

\section{Determinants of seropositivity among HPV-18 DNA positive women}

Analyses that parallel those reported above for HPV-16 were performed to evaluate possible determinants of
anti-HPV18 seropositivity among HPV-18 DNA positive women. Results are summarized in Tables 4 and 5 . Women who reported having sexual intercourse 2-3 times a month were less likely to be seropositive (compared to women having intercourse less than twice a month); however this finding may be spurious since few women fell into this category. Compared to never users of hormonal contraceptives, current users of oral contraceptives but not injectables had increased detection of anti-HPV18 antibodies (OR 2.47, 95\% CI 1.08-5.65). Also, when we evaluated antibody levels among anti-HPV-18 seropositive women by strata of hormonal contraceptives, we found that current users of oral contraceptives had significantly higher levels of anti-HPV18 $(\mathrm{GM}=49.0$ for never users, 30.4 for users in the past, 73.2 for current oral contraceptives users, 36.4 for current injectable users; $\mathrm{p}=0.04$ ).

\section{Discussion}

We assessed the prevalence and determinants of serological response to HPV-16 and HPV-18 infections in a group of 646 women 18-25 years of age with concomitant detection of HPV-16 and/or HPV-18 at the cervix. One strength of this analysis is that unlike previous studies that evaluated determinants of anti-HPV seropositivity irrespective of cervical HPV infection status $[5-7,9,10,20,21]$, our analysis was restricted to women with detectable cervical HPV infection and enabled us to focus on factors associated with seropositivity given prevalent HPV infection, also our study included a large population of young women infected with HPV-16/18, this group is of particular interest since the majority of HPV infections are acquired shortly after sexual debut.

The main finding is the observation that factors associated with sustained HPV exposure (elevated HPV viral load or cytological evidence of HPV infection), were positively associated with anti-HPV16 seropositivity. We also observed that lifetime number of sexual partners and possibly frequency of sexual intercourse were associated with anti-HPV16 seropositivity. To the extent that these factors reflects increased amount of viral exposure among infected women, this finding might also corroborate the association between viral load and seropositivity.

Table 3 Geometric mean for viral load (Hybrid capture, rlu/co values) stratified by use of hormonal contraceptives; NOTE. rlu/co, relative light units/cutoff

\begin{tabular}{lcc}
\hline Women characteristics & Geometric mean of Hybrid capture rlu/co values & $\mathbf{p}^{\mathbf{1}}$ \\
\hline Use of hormonal contraceptives & 40.0 \\
Never & 25.8 \\
In the past & 30.1 \\
Current oral contraceptives & 25.9 \\
Current injectable & 0.66 \\
\hline
\end{tabular}

${ }^{1} \mathrm{~F}$ test for differences in mean log transformed hybrid capture rlu/co values. 
Table 4 Determinants of seropositivity among HPV-18 DNA positive women at enrollment; Demographic and sexual factors

\begin{tabular}{|c|c|c|c|c|c|c|c|}
\hline \multirow[t]{2}{*}{ Women characteristics } & \multicolumn{3}{|c|}{ Anti-HPV18 } & \multicolumn{2}{|c|}{ Unadjusted } & \multicolumn{2}{|c|}{ Final model $^{1}$} \\
\hline & Negative & Positive & $\%$ & OR & $(95 \% \mathrm{Cl})$ & OR & $(95 \% \mathrm{Cl})$ \\
\hline All women & 76 & 103 & 57.5 & & & & \\
\hline \multicolumn{8}{|l|}{ Age } \\
\hline 18-19 & 17 & 27 & 61.4 & 1.00 & & 1.00 & \\
\hline $20-21$ & 25 & 31 & 55.4 & 0.78 & $(0.35-1.74)$ & 0.83 & $(0.36-1.91)$ \\
\hline $22-23$ & 21 & 24 & 53.3 & 0.72 & $(0.31-1.67)$ & 0.85 & $(0.30-2.40)$ \\
\hline $24-25$ & 13 & 21 & 61.8 & 1.02 & $(0.41-2.55)$ & 1.23 & $(0.39-3.85)$ \\
\hline$p$ trend & & & & & 0.9 & & 0.73 \\
\hline \multicolumn{8}{|l|}{ Age at sexual debut } \\
\hline$\geq 18$ & 24 & 21 & 46.7 & 1.00 & & 1.00 & \\
\hline 17 & 13 & 26 & 66.7 & 2.29 & $(0.94-5.55)$ & 2.29 & $(0.94-5.55)$ \\
\hline 16 & 12 & 21 & 63.6 & 2.00 & $(0.80-5.02)$ & 2.00 & $(0.80-5.02)$ \\
\hline 15 & 17 & 14 & 45.2 & 0.94 & $(0.38-2.36)$ & 0.94 & $(0.38-2.36)$ \\
\hline$<15$ & 10 & 21 & 67.7 & 2.40 & $(0.92-6.23)$ & 2.40 & $(0.92-6.23)$ \\
\hline$p$ trend & & & & & 0.3 & & 0.36 \\
\hline \multicolumn{8}{|c|}{ Years since first sexual intercourse } \\
\hline$\leq 1$ & 9 & 11 & 55.0 & 1.00 & & 1.00 & \\
\hline $2-3$ & 18 & 30 & 62.5 & 1.36 & $(0.47-3.92)$ & 1.25 & $(0.40-3.93)$ \\
\hline $4-5$ & 18 & 23 & 56.1 & 1.05 & $(0.36-3.06)$ & 0.87 & $(0.28-2.75)$ \\
\hline$\geq 6$ & 31 & 39 & 55.7 & 1.03 & $(0.38-2.80)$ & 0.77 & $(0.25-2.41)$ \\
\hline $\mathrm{p}$ trend & & & & & 0.7 & & 0.32 \\
\hline \multicolumn{8}{|c|}{ Frequency sexual intercourse, month } \\
\hline$\leq 1$ & 17 & 21 & 55.3 & 1.00 & & 1.00 & \\
\hline $2-3$ & 18 & 7 & 28.0 & 0.31 & $(0.11-0.93)$ & 0.25 & $(0.08-0.78)$ \\
\hline $4-9$ & 24 & 35 & 59.3 & 1.18 & $(0.52-2.69)$ & 0.97 & $(0.39-2.39)$ \\
\hline$\geq 10$ & 16 & 39 & 70.9 & 1.97 & $(0.83-4.68)$ & 1.47 & $(0.57-3.81)$ \\
\hline $\mathrm{p}$ trend & & & & & 0.0 & & 0.13 \\
\hline \multicolumn{8}{|c|}{ Lifetime number of sexual partners } \\
\hline 1 & 20 & 28 & 58.3 & 1.00 & & 1.00 & \\
\hline 2 & 18 & 22 & 55.0 & 0.87 & $(0.37-2.04)$ & 0.89 & $(0.37-2.15)$ \\
\hline$\geq 3$ & 38 & 53 & 58.2 & 1.00 & $(0.49-2.02)$ & 1.02 & $(0.48-2.17)$ \\
\hline$p$ trend & & & & & 0.9 & & 0.91 \\
\hline \multicolumn{8}{|c|}{ Time with most recent partner, months } \\
\hline$<4$ & 18 & 24 & 57.1 & 1.00 & & 1.00 & \\
\hline $4-13$ & 26 & 34 & 56.7 & 0.98 & $(0.44-2.17)$ & 0.81 & $(0.35-1.91)$ \\
\hline$>13$ & 32 & 45 & 58.4 & 1.05 & $(0.49-2.26)$ & 0.84 & $(0.35-2.04)$ \\
\hline $\mathrm{p}$ trend & & & & & 0.8 & & 0.74 \\
\hline
\end{tabular}

NOTE. HPV, human papillomavirus; OR, odds ratio; Cl, confidence interval.

${ }^{1}$ For each variable considered the final model adjusts for all variables that changed the crude estimate of risk by $15 \%$ or more.

Age: was adjusted for years since first sexual intercourse.

Age at sexual debut: was not adjusted for any co-factors since none of the potential confounders evaluated changed the OR estimates by $15 \%$ or more. Years since first sexual intercourse: was adjusted for use of hormonal contraceptives.

Frequency sexual intercourse, month: was adjusted for use of hormonal contraceptives.

Lifetime number of sexual partners: was adjusted for time with most recent partner.

Time with most recent partner: was adjusted for lifetime number of sexual partners and use of hormonal contraceptives.

We also observed a positive association between current hormonal contraceptive use (oral or injectable contraceptives) and anti-HPV16 seropositivity. The effect of current oral contraceptive use on seropositivity was also observed for anti-HPV18 antibodies. We initially hypothesized that this finding could reflect increased viral load among hormonal contraceptive users given that previous studies suggested that HPV contains hormonal responsive elements and that hormonal exposure may increase viral replication[18]. However, we saw no evidence that $\mathrm{HC} 2$ viral load was higher among current users of hormonal contraceptives, suggesting that 
Table 5 Determinants of seropositivity among HPV-18 DNA positive women; Contraceptive, pregnancy, smoking status factors

\begin{tabular}{|c|c|c|c|c|c|c|c|}
\hline \multirow[t]{2}{*}{ Women characteristics } & \multicolumn{3}{|c|}{ Anti-HPV18 } & \multicolumn{2}{|c|}{ Unadjusted } & \multicolumn{2}{|c|}{ Final model ${ }^{1}$} \\
\hline & Negative & Positive & $\%$ & OR & $(95 \% \mathrm{CI})$ & OR & $(95 \% \mathrm{Cl})$ \\
\hline All women & 76 & 103 & 57.5 & & & & \\
\hline \multicolumn{8}{|c|}{ Use of hormonal contraceptives } \\
\hline Never & 17 & 14 & 45.2 & 1.00 & & 1.00 & \\
\hline In the past & 19 & 18 & 48.7 & 1.15 & $(0.44-3.00)$ & 1.15 & $(0.44-3.00)$ \\
\hline Current oral contraceptives & 31 & 63 & 67.0 & 2.47 & $(1.08-5.65)$ & 2.47 & $(1.08-5.65)$ \\
\hline Current injectable & 9 & 8 & 47.1 & 1.08 & $(0.33-3.53)$ & 1.08 & $(0.33-3.53)$ \\
\hline \multicolumn{8}{|l|}{ Use of condom } \\
\hline Never & 27 & 41 & 60.3 & 1.00 & & 1.00 & \\
\hline In the past & 33 & 40 & 54.8 & 0.80 & $(0.41-1.56)$ & 0.87 & $(0.43-1.74)$ \\
\hline Current (last month) & 16 & 22 & 57.9 & 0.91 & $(0.40-2.03)$ & 1.19 & $(0.51-2.80)$ \\
\hline \multicolumn{8}{|l|}{ Frequency of condom use } \\
\hline Never or rarely & 31 & 50 & 61.7 & 1.00 & & 1.00 & \\
\hline Sometimes & 10 & 13 & 56.5 & 0.81 & $(0.32-2.06)$ & 0.80 & $(0.31-2.11)$ \\
\hline Most of the time & 15 & 18 & 54.6 & 0.74 & $(0.33-1.69)$ & 0.93 & $(0.40-2.17)$ \\
\hline Always & 19 & 22 & 53.7 & 0.72 & $(0.34-1.53)$ & 0.80 & $(0.37-1.76)$ \\
\hline \multicolumn{8}{|c|}{ Use of condom last sexual intercourse } \\
\hline No & 54 & 75 & 58.1 & 1.00 & & 1.00 & \\
\hline Yes & 22 & 28 & 56.0 & 0.92 & $(0.47-1.77)$ & 1.23 & $(0.60-2.56)$ \\
\hline \multicolumn{8}{|l|}{ Number of pregnancies } \\
\hline 0 & 38 & 44 & 53.7 & 1.00 & & 1.00 & \\
\hline 1 & 25 & 39 & 60.9 & 1.35 & $(0.69-2.62)$ & 1.35 & $(0.69-2.62)$ \\
\hline 2 & 11 & 13 & 54.2 & 1.02 & $(0.41-2.54)$ & 1.02 & $(0.41-2.54)$ \\
\hline$\geq 3$ & 2 & 7 & 77.8 & 3.02 & $(0.59-15.43)$ & 3.02 & $(0.59-15.43)$ \\
\hline $\mathrm{p}$ trend & & & & & 0.29 & & 0.2 \\
\hline \multicolumn{8}{|l|}{ Smoking Status } \\
\hline Never smoked for $\geq 6$ months & 56 & 75 & 57.3 & 1.00 & & 1.00 & \\
\hline Former smoker & 3 & 8 & 72.7 & 1.99 & $(0.51-7.85)$ & 1.99 & $(0.51-7.85)$ \\
\hline Current & 17 & 20 & 54.1 & 0.88 & $(0.42-1.83)$ & 0.88 & $(0.42-1.83)$ \\
\hline \multicolumn{8}{|c|}{ Cytology-Hybrid capture, viral load ${ }^{2}$} \\
\hline Normal/Low viral load & 34 & 45 & 57.0 & 1.00 & & 1.00 & \\
\hline LSIL-HSIL/Low viral load & 4 & 8 & 66.7 & 1.51 & $(0.42-5.44)$ & 1.51 & $(0.42-5.44)$ \\
\hline Normal/High viral load & 12 & 11 & 47.8 & 0.69 & $(0.27-1.76)$ & 0.69 & $(0.27-1.76)$ \\
\hline LSIL-HSIL/High viral load & 24 & 36 & 60.0 & 1.13 & $(0.57-2.24)$ & 1.13 & $(0.57-2.24)$ \\
\hline
\end{tabular}

NOTE. OR, odds ratio; Cl, confidence interval; LSIL, low grade squamous intraepithelial lesion; HSIL, high grade squamous intraepithelial lesion; HPV, human papillomavirus.

1 For each variable considered the final model adjusts for all variables that changed the crude estimate of risk by $15 \%$ or more.

Use of hormonal contraceptives: was not adjusted for any co-factors since none of the potential confounders evaluated changed the OR estimates by $15 \%$ or more.

Use of condom: was adjusted for use of hormonal contraceptives.

Frequency of condom use: was adjusted for use of hormonal contraceptives.

Use of condom last sexual intercourse: was adjusted for use of hormonal contraceptives.

Number of pregnancies, smoking status and cytology-hybrid capture, viral load: were not adjusted for any co-factors since none of the potential confounders evaluated changed the OR estimates by $15 \%$ or more.

${ }^{2}$ Low viral load defined as hybrid capture RLU/CO $\leq 30$; High viral load defined as hybrid capture RLU/CO > 30 .

alternative explanations are needed to explain the association we observed between current hormonal contraceptive use and anti-HPV seropositivity. One explanation could be that hormonal factors impact the immune response directly, and thus help regulate antibody production in response to HPV infection [22,23].
Therefore, we did observe suggestive, but not statistically significant, evidence of increasing anti-HPV16 and anti-HPV18 seropositivity with increasing numbers of pregnancies.

The main limitation of our study is its cross-sectional nature. Since HPV DNA infection and anti-HPV 
antibodies were assessed at the same timepoint, we cannot determine the amount of time each woman had been infected with HPV-16 and/or HPV-18 at the time of DNA and serum sample collection. Studies that have evaluated time between HPV infection and seroconversion have suggested that, on average, antibody seroconversion occurs 8-12 months after infection, although these studies did not sample frequently enough $[1,2]$. We attempted to account for time since infection by evaluating sexual behavior variables that we believe are correlates of time since exposure/infection, such as time since sexual debut (under the assumption that HPV infection is common and that exposure/infection typically occurs proximal to sexual debut) and time with most recent partner (under the assumption that new exposures/infections are likely to occur at the start of a new relationship). While our results did suggest that seropositivity was associated with longer time with the most recent partner the effect was not statistically significant.

Overall, detection of anti-HPV16 and anti-HPV18 antibodies was observed among $63.0 \%$ and $57.5 \%$ of women infected with HPV-16 or HPV-18, respectively; this seropositivity is consistent with that reported by other investigators that about half of HPV-16 or HPV18 DNA positive women are seropositive $[7,10,24]$.

Despite similar rates of anti-HPV16 and anti-HPV18 seropositivity, our findings for determinants of antiHPV18 seropositivity were less clear. The only significant predictor of anti-HPV18 seropositivity among HPV-18 infected women was current oral contraceptive use. Possible explanations include differences in the performance of the ELISA assays designed to measure antibodies against HPV-16 and HPV-18, lower power for the HPV-18 analysis since the number of HPV-18 infected women $(n=179)$ was smaller than that of HPV16 infected women $(n=484)$, or true biological differences resultant from differences in patterns/location of infections caused by these two viruses. The later statement is supported by reports that HPV-18 infections are often under-represented in precancers, and that they are preferentially associated with the development of cervical adenocarcinomas that often arise deep in the endocervical canal $[25,26]$.

\section{Conclusions}

Our evaluation of the prevalence and determinants of anti-HPV16 and anti-HPV18 seropositivity among women with concurrent cervical infection with HPV-16 and/or HPV-18 shows that over half of HPV-16/18 infected women had detectable levels of antibodies to the HPV type with which they were infected. Factors associated with sustained HPV exposure were predictive of seropositivity (including cytology and viral load measures) as was current hormonal contraceptive use, suggesting a possible effect of hormones on immune responses to HPV. Findings were clearer for HPV-16 than for HPV-18, suggesting the need for additional studies to understand whether these differences are biologically driven or resultant from study design or assay performance. Longitudinal studies that evaluate incidently detected HPV infections and follow these infections to determine whether seroconversion occurs and their determinants are needed.

\section{Acknowledgements}

The authors express special thanks to the women of Guanacaste and Puntarenas, Costa Rica, who take part in our Costa Rican HPV Vaccine Trial and to the staff in Costa Rica for their dedicated work.

The names and affiliations of the members of the CVT group are as follows: Proyecto Epidemiológico Guanacaste, Fundación INCIENSA, San José, Costa Rica: Mario Alfaro (Cytologist), Manuel Barrantes (Field Supervisor), María Concepcion Bratti (co-Investigator), Fernando Cárdenas (General Field Supervisor), Bernal Cortés (Specimen and Repository Manager), Albert Espinoza (Head, Coding and Data Entry), Yenory Estrada (Pharmacist), Paula González (co-Investigator), Diego Guillén (Pathologist), Rolando Herrero (coPrincipal Investigator), Silvia E. Jiménez (Trial Coordinator), Jorge Morales (Colposcopist), Lidia Ana Morera (Head Study Nurse), Elmer Pérez (Field Supervisor), Carolina Porras (co-Investigator), Ana Cecilia Rodriguez (coInvestigator), Maricela Villegas (Clinic M.D.)

University of Costa Rica, San José, Costa Rica: Enrique Freer (Director, HPV Diagnostics Laboratory), Jose Bonilla (Head, HPV Immunology Laboratory), Sandra Silva (Head Technician, HPV Diagnostics Laboratory), Ivannia Atmella (Immunology Technician), Margarita Ramírez (Immunology Technician). National Cancer Institute, Bethesda, MD, USA: Allan Hildesheim (co-Principal Investigator), Douglas R. Lowy (HPV Virologist), Nora Macklin (Trial Coordinator), Mark Schiffman (Co-Project Officer \& Medical Monitor), John T. Schiller (HPV Virologist), Mark Sherman (QC Pathologist), Diane Solomon (Medical Monitor \& QC Pathologist), Sholom Wacholder (Statistician). SAIC, NCl-Frederick, Frederick, MD, USA: Ligia Pinto (Head, HPV Immunology Laboratory), Alfonso Garcia-Pineres (Scientist, HPV Immunology Laboratory). Womens and Infants' Hospital, Providence, RI, USA: Claire Eklund (QC Cytology), Martha Hutchinson (QC Cytology).

DDL Diagnostic Laboratory, Voorburg, The Netherlands: Wim Quint (HPV DNA Testing), Leen-Jan van Doorn (HPV DNA Testing)

\section{Funding}

The Costa Rican Vaccine Trial is a longstanding collaboration between investigators in Costa Rica and NCl. The trial is sponsored and funded by $\mathrm{NCl}$ (N01-CP-11005) with support from the NIH Office for Research on Women's Health and conducted in agreement with the Ministry of Health of Costa Rica. Vaccine was provided for our trial by GSK Biologicals, under a Clinical Trials Agreement with NCl. GSK also provided support for aspects of the trial associated with the regulatory submission needs of the company under FDA BB-IND 7920. NCl and Costa Rican investigators make final editorial decisions on this presentation and subsequent publications. CP was supported by an appointment to the senior fellowship programme at the National Institutes of Health. The programme is administered by the Oak Ridge Institute for Science and Education through an interagency agreement between the US Department of Energy and the National Institutes of Health

\section{Author details}

${ }^{1}$ Division of Cancer Epidemiology and Genetics, National Cancer Institute, Bethesda, MD, USA. ${ }^{2}$ Proyecto Epidemiológico Guanacaste, Fundación INCIENSA, Liberia, Costa Rica. ${ }^{3}$ Women and Infants' Hospital, Providence, Rhode Island; USA. ${ }^{4}$ DDL Diagnostic Laboratory, Voorburg, The Netherlands. ${ }^{5}$ GlaxoSmithKline Biologicals, Rixensart, Belgium.

\section{Authors' contributions}

All authors contributed to and approved the final version of the manuscript. $\mathrm{CP}, \mathrm{CB}$ and $\mathrm{AH}$ performed the analysis of data and wrote the first draft of 
the manuscript. AC, RH, SW, DS, MSC and AH designed the study. CP, AC, $\mathrm{RH}, \mathrm{PG}, \mathrm{SJ}, \mathrm{AH}$ were responsible for the coordination of the study and recruitment of the participants. LJVD and WQ were responsible for the HPV DNA testing. CB was responsible for the testing of HPV-16/18 antibodies by ELISA. MSa, SC participated in the analysis of data. MH carried out the cytological interpretations.

\section{Competing interests}

Wim Quint and Leen-Jan van Doorn are employees of DDL Diagnostic Laboratory; Catherine Bougelet is an employee of GSK Biologicals. None of the authors have any potential conflicts of interest to report.

\section{Received: 2 June 2010 Accepted: 11 August 2010}

Published: 11 August 2010

\section{References}

1. Carter JJ, Koutsky LA, Hughes JP, Lee SK, Kuypers J, Kiviat N, Galloway DA: Comparison of human papillomavirus types 16, 18, and 6 capsid antibody responses following incident infection. J Infect Dis 2000, 181:1911-1919.

2. Ho GY, Studentsov YY, Bierman R, Burk RD: Natural history of human papillomavirus type 16 virus-like particle antibodies in young women. Cancer Epidemiol Biomarkers Prev 2004, 13:110-116.

3. Frazer I: Correlating immunity with protection for HPV infection. Int J Infect Dis 2007, 11(Suppl 2):S10-16.

4. Stanley M: Immune responses to human papillomavirus. Vaccine 2006, 24(Suppl 1):S16-22.

5. Nonnenmacher B, Pintos J, Bozzetti MC, Mielzinska-Lohnas I, Lorincz AT, Ikuta N, Schwartsmann G, Villa LL, Schiller JT, Franco E: Epidemiologic correlates of antibody response to human papillomavirus among women at low risk of cervical cancer. Int J STD AIDS 2003, 14:258-265.

6. Stone KM, Karem KL, Sternberg MR, McQuillan GM, Poon AD, Unger ER, Reeves WC: Seroprevalence of human papillomavirus type 16 infection in the United States. J Infect Dis 2002, 186:1396-1402.

7. Wang SS, Schiffman M, Shields TS, Herrero R, Hildesheim A, Bratti MC, Sherman ME, Rodriguez AC, Castle PE, Morales J, et al: Seroprevalence of human papillomavirus-16, $-18,-31$, and -45 in a population-based cohort of 10000 women in Costa Rica. Br J Cancer 2003, 89:1248-1254.

8. Naud P, Matos J, Hammes L, Stuckzynski J, Brouwers K, Magno V, Dias E, Crusius P, d'Avila A, Campos C, et al: Factors predicting intermediate endpoints of cervical cancer and exposure to human papillomavirus (HPV) infections in young women screened as potential targets for prophylactic HPV vaccination in south of Brazil. Eur J Obstet Gynecol Reprod Biol 2006, 124:110-118.

9. Shin HR, Lee DH, Herrero R, Smith JS, Vaccarella S, Hong SH, Jung KY, Kim HH, Park UD, Cha HS, et al: Prevalence of human papillomavirus infection in women in Busan, South Korea. Int J Cancer 2003, 103:413-421.

10. Viscidi RP, Kotloff KL, Clayman B, Russ K, Shapiro S, Shah KV: Prevalence of antibodies to human papillomavirus (HPV) type 16 virus-like particles in relation to cervical HPV infection among college women. Clin Diagn Lab Immunol 1997, 4:122-126.

11. Herrero R, Hildesheim A, Rodriguez AC, Wacholder S, Bratti C, Solomon D, Gonzalez P, Porras C, Jimenez S, Guillen D, et al: Rationale and design of a community-based double-blind randomized clinical trial of an HPV 16 and 18 vaccine in Guanacaste, Costa Rica. Vaccine 2008, 26:4795-4808.

12. Castle PE, Porras C, Quint WG, Rodriguez AC, Schiffman M, Gravitt PE, Gonzalez P, Katki HA, Silva S, Freer E, et al: Comparison of two PCR-based human papillomavirus genotyping methods. $J$ Clin Microbiol 2008, 46:3437-3445.

13. Baay MF, Quint WG, Koudstaal J, Hollema H, Duk JM, Burger MP, Stolz E, Herbrink P: Comprehensive study of several general and type-specific primer pairs for detection of human papillomavirus DNA by PCR in paraffin-embedded cervical carcinomas. J Clin Microbiol 1996, 34:745-747.

14. van Doorn LJ, Molijn A, Kleter B, Quint W, Colau B: Highly effective detection of human papillomavirus 16 and 18 DNA by a testing algorithm combining broad-spectrum and type-specific PCR. J Clin Microbiol 2006, 44:3292-3298.

15. Dessy FJ, Giannini SL, Bougelet CA, Kemp TJ, David MP, Poncelet SM, Pinto LA, Wettendorff MA: Correlation between direct ELISA, single epitope-based inhibition ELISA and pseudovirion-based neutralization assay for measuring anti-HPV-16 and anti-HPV-18 antibody response after vaccination with the AS04-adjuvanted HPV-16/18 cervical cancer vaccine. Hum Vaccin 2008, 4:425-434.

16. Harper DM, Franco EL, Wheeler C, Ferris DG, Jenkins D, Schuind A, Zahaf T, Innis B, Naud P, De Carvalho NS, et al: Efficacy of a bivalent L1 virus-like particle vaccine in prevention of infection with human papillomavirus types 16 and 18 in young women: a randomised controlled trial. Lancet 2004, 364:1757-1765.

17. Coseo S, Porras C, Hildesheim A, Rodriguez AC, Schiffman M, Herrero R, Wacholder S, Gonzalez P, Wang SS, Sherman ME, et al: Seroprevalence and Determinants of Human Papillomavirus 16/18 Seropositivity among Young Women in Costa Rica. Sex Transm Dis 2009.

18. de Villiers EM: Relationship between steroid hormone contraceptives and HPV, cervical intraepithelial neoplasia and cervical carcinoma. Int J Cancer 2003, 103:705-708.

19. Green J, de Gonzalez Berrington A, Smith JS, Franceschi S, Appleby P, Plummer M, Beral V: Human papillomavirus infection and use of oral contraceptives. Br J Cancer 2003, 88:1713-1720.

20. Clifford GM, Shin HR, Oh JK, Waterboer T, Ju YH, Vaccarella S, Quint W, Pawlita M, Franceschi S: Serologic response to oncogenic human papillomavirus types in male and female university students in Busan, South Korea. Cancer Epidemiol Biomarkers Prev 2007, 16:1874-1879.

21. Dondog B, Clifford GM, Vaccarella S, Waterboer T, Unurjargal D, Avirmed D, Enkhtuya S, Kommoss F, Wentzensen N, Snijders PJ, et al: Human papillomavirus infection in Ulaanbaatar, Mongolia: a population-based study. Cancer Epidemiol Biomarkers Prev 2008, 17:1731-1738.

22. Kovacic MB, Katki HA, Kreimer AR, Sherman ME: Epidemiologic analysis of histologic cervical inflammation: relationship to human papillomavirus infections. Hum Pathol 2008, 39:1088-1095.

23. Safaeian M, Falk RT, Rodriguez AC, Hildesheim A, Kemp T, Williams M, Morera L, Barrantes M, Herrero R, Porras C, Pinto L: Factors associated with fluctuations in $\lg A$ and $\lg G$ levels at the cervix during the menstrual cycle. J Infect Dis 2009, 199:455-463.

24. Wideroff $L$, Schiffman MH, Hoover R, Tarone RE, Nonnenmacher B, Hubbert N, Kirnbauer R, Greer CE, Lorincz AT, Manos MM, et al: Epidemiologic determinants of seroreactivity to human papillomavirus (HPV) type 16 virus-like particles in cervical HPV-16 DNA-positive andnegative women. J Infect Dis 1996, 174:937-943.

25. Bulk S, Berkhof J, Bulkmans NW, Zielinski GD, Rozendaal L, van Kemenade FJ, Snijders PJ, Meijer CJ: Preferential risk of HPV16 for squamous cell carcinoma and of HPV18 for adenocarcinoma of the cervix compared to women with normal cytology in The Netherlands. $\mathrm{Br}$ J Cancer 2006, 94:171-175.

26. Schiffman M, Herrero R, Desalle R, Hildesheim A, Wacholder S, Rodriguez AC, Bratti MC, Sherman ME, Morales J, Guillen D, et al: The carcinogenicity of human papillomavirus types reflects viral evolution. Virology 2005, 337:76-84.

\section{Pre-publication history}

The pre-publication history for this paper can be accessed here: http://www.biomedcentral.com/1471-2334/10/238/prepub

\section{doi:10.1186/1471-2334-10-238}

Cite this article as: Porras et al:: Determinants of seropositivity among HPV-16/18 DNA positive young women. BMC Infectious Diseases 2010 10:238.

\section{Submit your next manuscript to BioMed Central and take full advantage of:}

- Convenient online submission

- Thorough peer review

- No space constraints or color figure charges

- Immediate publication on acceptance

- Inclusion in PubMed, CAS, Scopus and Google Scholar

- Research which is freely available for redistribution 